\title{
Spatial and Temporal Analyses of Bacterial Blight of Onion Caused by Xanthomonas axonopodis pv. allii
}

\author{
P. Roumagnac, O. Pruvost, F. Chiroleu, and G. Hughes
}

First, second, and third authors: CIRAD, UMR Peuplements Végétaux et Bioagresseurs en Milieu Tropical CIRAD-Université de la Réunion, Pôle de Protection des Plantes, 7, chemin de l'Irat, 97410 Saint Pierre, Réunion Island, France; and fourth author: School of Biological Sciences, University of Edinburgh, West Mains Road, Edinburgh EH9 3JG, UK.

Accepted for publication 7 September 2003.

\section{ABSTRACT}

Roumagnac, P., Pruvost, O., Chiroleu, F., and Hughes, G. 2004. Spatial and temporal analyses of bacterial blight of onion caused by Xanthomonas axonopodis pv. allii. Phytopathology 94:138-146.

Bacterial blight of onion is a severe disease, which emerged over the past decade in several onion-producing areas. This disease currently is observed in both the Old and New Worlds. Although the causative agent, Xanthomonas axonopodis pv. allii, is potentially seedborne, seed transmission and significance of seedborne initial inoculum for the development of bacterial blight of onion previously has not been assessed. This article describes experimental work designed to evaluate the biological importance of seedborne $X$. axonopodis pv. allii as an initial inoculum source, and examine the temporal and spatial dynamics of the disease. Over 3 years, outbreaks of bacterial blight of onion always were induced in experimental plots sown with naturally contaminated seed lots, with a contamination rate determined as $0.04 \%$. Analyses of disease patterns indicated a likely seedborne origin for the inoculum associated with the early stages of epidemics. Spatial analyses performed with several statistical methods indicated aggregated patterns of disease incidence data. Primary foci enlarged over time, and a few distinct secondary foci sometimes were established after occurrence of wind-driven rains (with gusts up to $15 \mathrm{~m} \mathrm{~s}^{-1}$ ). Distances between primary and secondary foci ranged from less than $1 \mathrm{~m}$ (satellite foci) to $25 \mathrm{~m}$. It remains possible that longdistance dispersal of inoculum was at least partly involved in the later stages of epidemics.

Additional keywords: beta-binomial distribution, goestatistics, spatial autocorrelation.
Bacterial blight of onion (BBO) is a foliar disease causing epidemics on onion (Allium cepa L.), garlic (A. sativum L.), and Welsh onion (A. fistulosum L.). The host range of Xanthomonas axonopodis pv. allii consists of different Allium spp.: onion, garlic, Welsh onion, shallot (A. cepa var. ascalonicum Backer), chive (A. schoenoprasum L.), and leek (A. porrum L.) (40). This disease was first observed in Barbados in 1971 (36). The causal bacterium, first identified as a Xanthomonas sp. in Hawaii in 1978 (1), recently was characterized by a polyphasic approach and classified as Xanthomonas axonopodis pv. allii (40). Recently, a worldwide increase of BBO occurrence has been reported. The disease emerged in the 1990s and early 2000s in several countries, including different states of the continental United States (17,34,43,50), Brazil (33), Japan (18), the Republic of South Africa (52), Venezuela (58), Caribbean Islands (35), and Réunion Island (41). X. axonopodis pv. allii induces symptoms that consist of lenticular water-soaked leaf spots, which turn into dry chlorotic lesions and eventually coalesce. When disease is severe, leaf dieback can occur, resulting in a reduction of bulb size. Therefore, crop yields could drastically decrease, and yield losses ranging from 10 to $50 \%$ have been reported in diseased fields in Colorado and California, respectively $(34,50)$. In semiarid environmental conditions prevailing in Colorado, maximum daily temperatures from 28 to $35^{\circ} \mathrm{C}$ during bulbing were favorable to the development of BBO. Early season conditions (i.e., before bulb initiation) were not associated with either disease appearance or severity (51).

Corresponding author: O. Pruvost; E-mail address: olivier.pruvost@ cirad.fr

Publication no. P-2003-1210-01R

(C) 2004 The American Phytopathological Society
Alvarez et al. (1) hypothesized that the emergence of BBO in cleared brushland of Molokai was connected with the importation of seed lots from mainland United States. However, attempts to isolate the causal bacterium from suspect onion seed lots were not successful, because of the lack of an efficient detection test. Recently, the detection of $X$. axonopodis pv. allii from onion seed lots originating from diseased fields confirmed that the pathogen is seedborne (41). More supporting data is needed to determine whether BBO epidemics can develop from seedborne inoculum. For several pathosystems involving xanthomonads, it has been shown that contaminated seed can act as an efficient long-distance spread mechanism (55).

Many xanthomonads associated with annual crops are seedborne (e.g., X. hortorum pv. carotae on carrot [23], X. translucens pv. translucens on wheat [59], X. axonopodis pv. phaseoli on bean [62], X. campestris pv. campestris on crucifers [46], and xanthomonads on pepper and tomato [2]). Little is known about temporal progress and spatial pattern of epidemics initiated with xanthomonads present as seedborne initial inoculum on vegetable crops. Spatiotemporal progress of $X$. campestris pv. campestris and cabbage black rot disease $(19,21,54)$ has been described but epidemics always were initiated from inoculated plants.

It is important to quantify distribution of disease incidence using contaminated seed as the source of initial inoculum. The knowledge gained from such epidemiological studies is essential to understand the transmission of the pathogen from seed to plant and its impact on the crop. Results derived from quantification of disease incidence have been used as aids to improve control (e.g., for developing sampling methods $[13,16,27]$ and predicting yield losses [16,29]). Characterization of the spatiotemporal dynamics of plant diseases is also a necessary first step before development of qualitative epidemiological analyses (i.e., population genetics applied to epidemiology). Several statistical methods available to 
quantify spatial patterns can provide important clues to plant disease epidemiology (24). A multicriterion approach to quantification of heterogeneity of disease incidence (i.e., measures of intracluster correlation with spatial point pattern analyses and measures of intercluster correlation with spatial autocorrelation and semivariance analysis) allows a more detailed interpretation of patterns (60). Spatial point pattern methods aim to assess the tendency for plants located in the same sampling unit to have the same disease status. Two methods have gained considerable popularity in recent years: (i) the fit to a beta-binomial distribution, which has been shown appropriate to characterize aggregation in disease incidence data $(15,26,28)$, and (ii) the binary form of Taylor's power law, which has been used for assessing aggregation of diseased plants $(14-16,28,44,60,61)$. The spatial dependence of disease incidence or disease severity among sampling units usually is assessed by spatial autocorrelation-based approaches $(3,7-9,10,32,37)$.

The purposes of this work were to (i) examine the temporal and spatial dynamics of $\mathrm{BBO}$, and (ii) determine whether $\mathrm{BBO}$ epidemics can develop from seedborne $X$. axonopodis pv. allii initial inoculum.

\section{MATERIALS AND METHODS}

Establishment of experimental plots. Experiments were performed at the CIRAD experimental station at Bassin Plat, Saint Pierre, Réunion Island, (elevation $150 \mathrm{~m}$ above sea level, latitude 21.310S, longitude 55.639E). This station was chosen because (i) it has no history of onion cropping, (ii) it is located away from the onion-growing area of Réunion Island, and (iii) the relatively dry climate allows the development of bacterial diseases but is not thought favorable to rapid spatial development of epidemics.

Experimental plots were sown with the same naturally $X$. axonopodis pv. allii-contaminated onion (A. cepa L. cv. Chateauvieux) seed lot. The seed contamination rate was calculated, based on analyses of 250 replicates each containing $1 \mathrm{~g}$ of seed randomly taken from the seed lot as described previously (41). Briefly, seed samples were soaked in $5 \mathrm{ml}$ of $0.01 \mathrm{M}$ sterile Tris buffer ( $\mathrm{pH} 7.2)$ for $48 \mathrm{~h}$ at $4^{\circ} \mathrm{C}$. Macerates and 10-fold dilutions were plated using a Spiral System device (Interscience, Saint Nom la Bretèche, France) on semiselective NCTM1 medium. Plates were incubated at $28^{\circ} \mathrm{C}$ for 4 days. The contamination rate ( $c r$ ) determined as

$$
c r=1-\left(\frac{A}{B}\right)^{\frac{1}{\eta}}
$$

where $A$ is the number of samples from which the pathogen was not isolated, $B$ is the total number of analyzed samples, and $\eta$ is the number of seeds per replicate sample $(\eta=245)(31)$. The contamination rate of seed was $\approx 0.04 \%$. X. axonopodis pv. allii population densities in contaminated samples ranged from $5.1 \times$ $10^{1}$ to $2.0 \times 10^{6} \mathrm{CFU} \mathrm{g}^{-1}$ of seed, with a median population size of $5.1 \times 10^{2} \mathrm{CFU} \mathrm{g}^{-1}$.

The experiment consisted of five plots, each of $100 \mathrm{~m}^{2}$. Plots were sown on 11 June $1999\left(\mathrm{P}_{1}\right), 10$ July $2000\left(\mathrm{P}_{2}\right.$ and $\left.\mathrm{P}_{3}\right)$, and 12 July $2001\left(\mathrm{P}_{4}\right.$ and $\left.\mathrm{P}_{5}\right)$, respectively. Over the 3 years, different sites were selected on the research station for plot establishment in order to avoid inoculum from previously infected onion debris. When two plots were established at the same time (as in 2000 and 2001), they were separated by $70 \mathrm{~m}$ and located on a line oriented at right angles to the prevailing wind direction. To prevent movement of inoculum from plot to plot, they were surrounded by seven rows of maize. Onion trap plants, consisting of 15 rows (sown $0.05 \mathrm{~m}$ apart within rows and $0.2 \mathrm{~m}$ apart across rows) and covering a total surface of $1,620 \mathrm{~m}^{2}$, were established around the maize windbreak with healthy onion seed (i.e., from seed lots with a contamination rate lower than one $X$. axonopodis pv. allii-contaminated seed per $10^{5}$ seed). The closest onion trap plants were $1.8 \mathrm{~m}$ from the maize windbreak. Onion and maize plants around the experimental plots were watered using drip irrigation.

Each experimental plot consisted of 41 rows of 200 onion plants, oriented downwind. Seed (which contained $0.04 \%$ X. axonopodis pv. allii-contaminated seed) were sown $0.05 \mathrm{~m}$ apart within rows and $0.25 \mathrm{~m}$ apart across rows. Thus, the potential number of onion plants per plot was 8,200 . Plots were subjected to overhead irrigation, using a central sprinkler. Plants were watered for 30 min twice a day (starting at 6:00 a.m. and 6:00 p.m.). Each plot received approximately $3.3 \mathrm{~mm}$ of water per day.

Climatic data, including minimum, maximum, and average temperature; minimum, maximum, and average humidity; rainfall; and wind speed and direction were recorded hourly during the experiments.

Disease assessment. The positions of missing plants were mapped 75 days after sowing for each experimental plot (except for plot $\mathrm{P}_{1}$ ). For plot $\mathrm{P}_{1}$, the number of plants per meter in each row was counted without mapping missing plants. $\mathrm{BBO}$ incidence was determined at 15- and 30-day intervals after emergence of leaves in experimental plots and outer rings composed of onion trap plants, respectively. Symptom development was recorded on each plant by visual assessment. All doubtful symptoms were assayed for the presence of xanthomonads by nondestructively swabbing lesions with $200 \mu \mathrm{l}$ of $0.01 \mathrm{M}$ sterile Sigma 7-9 buffer ( $\mathrm{pH}$ 7.2) and streaking aliquots on NCTM1 semiselective medium, as described previously (41).

Temporal analysis. Disease incidence, defined as the number of diseased plants divided by total number of plants in the plot, was calculated for each disease assessment date. Nonlinear logistic, probit, complementary log-log, Gompertz, and exponential models were fitted, and parameters were estimated for each plot using S-PLUS 6 (Insightful Corporation, Seattle, WA). The appropriateness of each model was assessed by examination of the residual plots, correlation analysis of observed versus predicted values, and use of the Akaike criterion (6). From the estimates of $r^{*}$ (rate of disease increase) and $K$ (maximum amount of disease, the asymptote of the disease progress curve) for each plot, the product $r^{*} K$, used as an overall (mean) measure of the absolute rate, was calculated (3). For each plot, the number of days after sowing corresponding to $0.5 \mathrm{~K}$ and corresponding asymptotic confidence intervals (95\%) were estimated for the selected model (12).

Spatial analyses. Distribution analyses. For each individual plot sown with $X$. axonopodis pv. allii-contaminated seed, binomial and beta-binomial distributions were fitted to the data using the computer programs EGRET for Windows (version 2.0; Cytel Software Corporation, Cambridge, MA) and BBD (25). For this purpose, each plot was divided into 100 sampling units (referred to as quadrats). Each quadrat had a size of $1 \mathrm{~m}^{2}$ and contained up to 80 plants. Fitting the beta-binomial distribution involves estimating the probability that a plant is diseased $(p)$ by the mean disease incidence $(\hat{p})$ and, in addition, a second parameter $(\theta)$ that characterizes variability in $p$. Because the number of plants per quadrat was not constant, it was not possible to calculate expected frequencies or perform $\chi^{2}$ goodness-of-fit tests. However, by calculating the likelihood ratio statistic (LRS), it was possible to determine whether the beta-binomial distribution provided a better fit than the binomial.

Binary power law analyses. The binary form of Taylor's power law (57) for disease incidence can be written as (14)

$$
V_{\mathrm{obs}}=A_{x} V_{\mathrm{ran}}^{b}
$$

where $V_{\text {obs }}$ is the observed sample variance, $V_{\text {ran }}$ is the theoretical random variance, and $A_{x}$ and $b$ are coefficients estimated by regression analysis (described in equation 5). For disease incidence data, the theoretical random variance is the binomial variance, estimated by $V_{\text {ran }}=V_{\text {bin }}=[\hat{p}(1-\hat{p}) / n]$, where $n$ is the number of 
plants per quadrat. Because the number of plants per quadrat was not constant, a mean value $\bar{n}$ was calculated as

$$
\bar{n}=\frac{\sum n_{i}}{N}
$$

where $n_{i}$ is the number of plants in each quadrat, $i=1,2, \ldots, N$, and $N=100$ is the total number of quadrats.

The (approximate) observed sample variance was calculated for each plot according to the formula of Cochran (5) for variable $n$ as

$$
V_{\mathrm{obs}}=\frac{\left\lfloor\sum n_{i}^{2}\left(y_{i}-\hat{p}\right)^{2}\right\rfloor}{\left[\bar{n}^{2}(N-1)\right]}
$$

where $y_{i}=X_{i} / n_{i}, \hat{p}=\Sigma X_{i} / \Sigma n_{i}$, and $X_{i}$ is the number of diseased plants in quadrat $i$, with $i=1,2, \ldots, N$. The power law model can then be written as

$$
\log \left(V_{\text {obs }}\right)=\log \left(A_{x}\right)+b \log [\hat{p}(1-\hat{p}) / \bar{n}]
$$

where $\log \left(A_{x}\right)$ and $b$ are the intercept and slope of a straight line, respectively. In equation 5 , a binomial distribution is indicated by $b=1$ and $A_{x}=1$. If $b=1$ and $A_{x}>1$, there is aggregation but the beta-binomial parameter $\theta$ does not depend on $p$. Finally, if $b>1$ and $A_{x}>1$ there is aggregation and the beta-binomial parameter $\theta$ depends on $p$ (i.e., the degree of aggregation changes with incidence). The number of individual data sets in each of the 3 years of experiment was too small to allow precise parameter estimation in the regression analysis; therefore, data sets were pooled for power law analysis. A total of 30 data sets (6 in 1999, 14 in 2000, and 10 in 2001), were combined and analyzed.

Spatial autocorrelation. The strength and directionality of aggregation of diseased plants in the five experimental plots were examined with spatial autocorrelation analysis using the LCOR2 software (10). For spatial analysis, the $x, y$ spatial location as well as the disease incidence (proportion of diseased plants) for each quadrat at each assessment date was used as input data. The LCOR2 software was used to calculate the following: the proximity patterns of lag positions with autocorrelations significantly greater than expected (SL+) (10); the size and shape of core and reflected clusters of positively correlated lag positions; the strength of aggregation (i.e., the proportion of lag positions within the extent of the core cluster that were significantly positive);
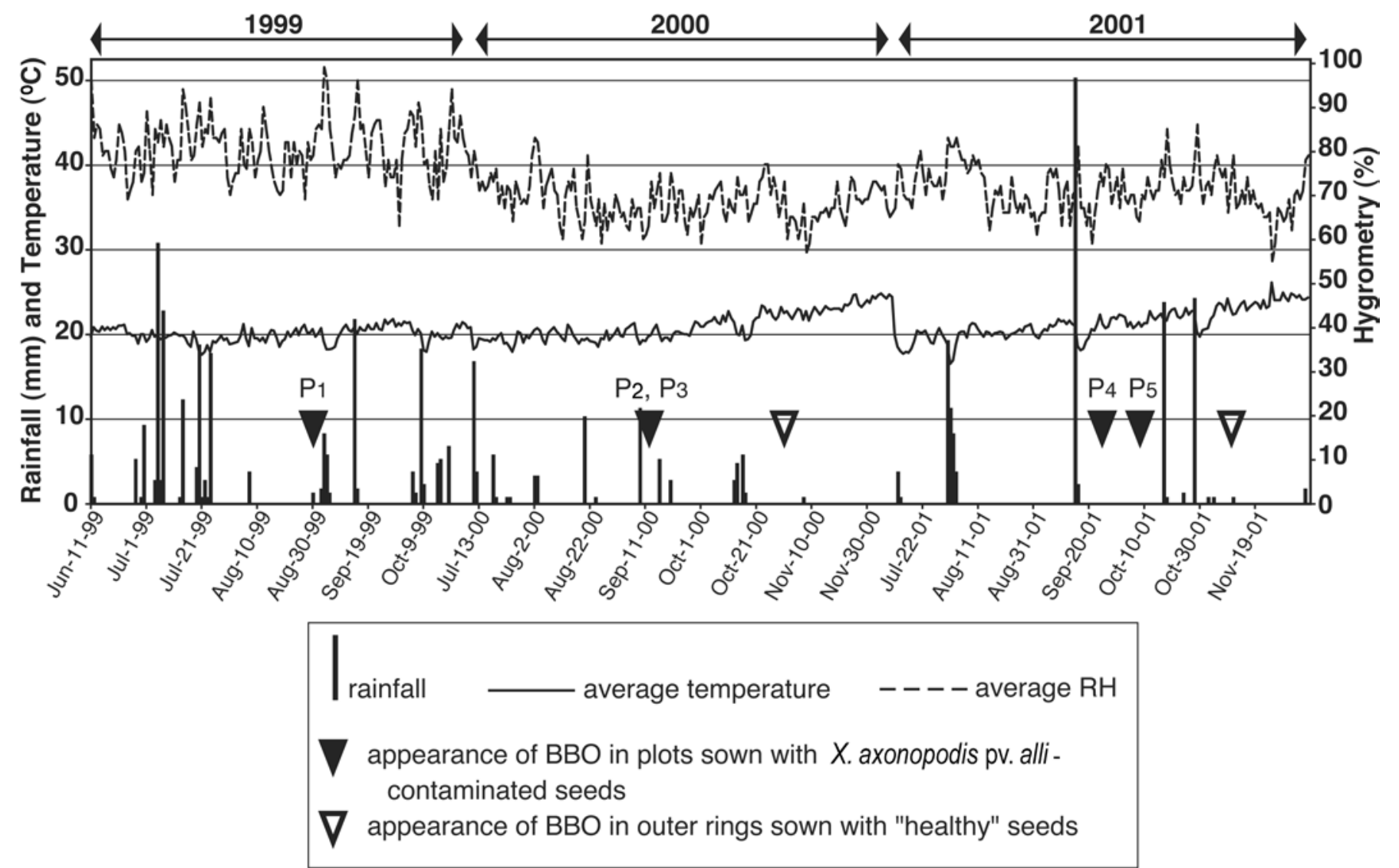

Fig. 1. Climatic conditions at the CIRAD station in Bassin Plat, Saint Pierre, Réunion Island (elevation $150 \mathrm{~m}$ above sea level, latitude $21.310 \mathrm{~S}$, longitude 55.639E). The dates when bacterial blight of onion appeared are represented with triangles. $\mathrm{P}_{i}(i=1,2,3,4$, or 5$)$ refers to the establishment date of plot $i$.

TABLE 1. Nonlinear regression analysis and associated statistics of the incidence of bacterial blight of onion in five plots sown with Xanthomonas axonopodis pv. allii-contaminated seed during three successive onion cropping seasons in Réunion Island

\begin{tabular}{lccccccc}
\hline Plot & $\begin{array}{c}\text { Rate } \\
\left(r^{*}\right)\end{array}$ & $\begin{array}{c}\text { Standard error } \\
\text { of } r^{*}\end{array}$ & $\begin{array}{c}\text { Maximum amount } \\
\text { of disease }(K)\end{array}$ & $\begin{array}{c}\text { Standard error } \\
\text { of } K\end{array}$ & $\begin{array}{c}\text { Absolute rate } \\
\left(r^{*} K\right)\end{array}$ & $R^{2 \mathrm{a}}$ & \begin{tabular}{c} 
No. of days, incidence $0.5 K^{\mathrm{b}}$ \\
\hline $\mathrm{P}_{1}$
\end{tabular} $\mathrm{P}_{2}$ \\
\hline $\mathrm{P}_{3}$ & 0.124 & 0.0036 & 0.126 & 0.00065 & 0.0156 & 0.999 & $107.3(106.95-107.63)$ \\
$\mathrm{P}_{4}$ & 0.064 & 0.0150 & 0.073 & 0.00511 & 0.0046 & 0.958 & $91.6(83.25-98.79)$ \\
$\mathrm{P}_{5}$ & 0.084 & 0.0099 & 0.158 & 0.00547 & 0.0124 & 0.990 & $108.8(105.20-112.16)$ \\
\end{tabular}

a Adjusted coefficient of multiple determination.

${ }^{b}$ Number of days after sowing for an incidence of $0.5 \mathrm{~K}$. Values in brackets are asymptotic confidence interval bounds (95\%). 
row effects (i.e., the number of SL+ distance positions in the first row (within) or in the first column (across) of the autocorrelation proximity pattern which are contiguous with the origin); the edge effect; and the strength of nonrandomness (i.e., the proportion of SL+ plus SL- positions within the proximity matrix) $(7,10)$.

Geostatistical analysis. Semivariance analyses were used to examine the spatial relationship among BBO-affected plants for plot $\mathrm{P}_{2}, \mathrm{P}_{3}$, and $\mathrm{P}_{4}$. Data sets were prepared as described previously $(11,37)$ by assigning a temporal value to each plant (i.e., the number of days of lesion-bearing relative to the final assessment date of the experiment). Thus, a plant was quantitatively weighted more heavily if it became infected earlier as opposed to later in the epidemic. Omnidirectional analyses were performed using GS+386 software (release 2.3; Gamma Design Software, Plainwell, MI) for $0^{\circ}$ relative to the axis of the row with a tolerance of $\pm 180^{\circ}$. Subsequent analyses were performed for $0,45,90$, and $135^{\circ}$ relative to the row with an angle of $\pm 90^{\circ}$ to look for anisotropy. Linear, exponential, spherical, linear-with-sill, and Gaussian transitional models were fitted to the standardized semivariance versus distance data by means of nonlinear regression analysis. Spherical, exponential, and Gaussian models commonly are used to fit clumped patterns (49). Residual sums of squares were used to choose between models. The selected models involved estimation of three parameters, the localized discontinuity or nugget variance $\left(C_{0}\right)$; the sill $\left(C_{0}+C\right)$, with $C$ being the structural variance; and the range of spatial dependency $\left(A_{0}\right)$. Low nugget values can be interpreted as high level of aggregation of disease incidence $(8,37)$. The range of spatial dependency is the maximum distance at which samples show spatial dependence. The spatiotemporal structure of diseased surfaces is considered anisotropic when directional semivariograms diverge from one another over distance (48). Diseased surfaces were interpolated through kriging from the original point data using the block method with GS+ geostatistical software (release 5.3b, Gamma Design Software). Two-dimensional maps of diseased surfaces were constructed in order to visualize primary foci and spread of the disease over time.

\section{RESULTS}

Disease assessment and climatic data. The mean number of plants per quadrat ( $\bar{n} \pm$ standard deviation) was $60.5 \pm 3.5$ for $\mathrm{P}_{1}$, $69.6 \pm 3.6$ for $\mathrm{P}_{2}, 69.7 \pm 3.4$ for $\mathrm{P}_{3}, 64.0 \pm 4.8$ for $\mathrm{P}_{4}$, and $62.2 \pm$ 4.1 for $\mathrm{P}_{5}$. Disease appeared on 31 August 1999 in $\mathrm{P}_{1}$, on 13 September 2000 in $\mathrm{P}_{2}$ and $\mathrm{P}_{3}$, on 26 September 2001 in $\mathrm{P}_{4}$, and on 10 October 2001 in $\mathrm{P}_{5}$ (Fig. 1). At the time of disease appearance, isolation of $X$. axonopodis pv. allii on the semiselective medium

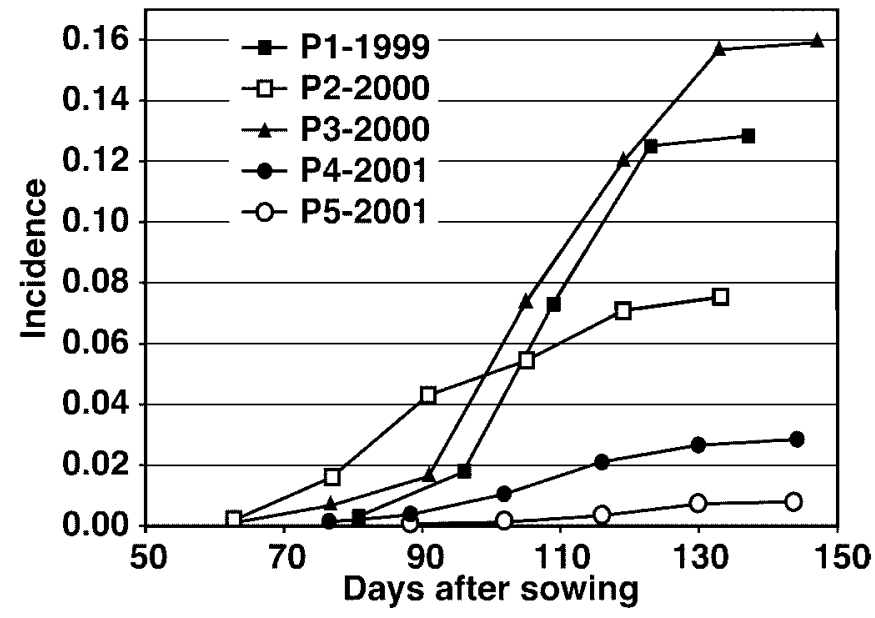

Fig. 2. Temporal disease progress of bacterial blight of onion in five experimental plots sown with Xanthomonas axonopodis pv. allii-contaminated seed during three successive onion cropping seasons in Réunion Island. indicated the presence of three primary foci in $\mathrm{P}_{1}, \mathrm{P}_{3}$, and $\mathrm{P}_{4}$, five foci in $\mathrm{P}_{2}$, and one focus in $\mathrm{P}_{5}$. Using a seed lot contamination rate of $0.04 \%$ and an overall value of 6,500 plants per experimental plot as the basis for calculation of the expected number of primary foci in a plot $(n=2.6)$, and then using this value as the basis for calculation of cumulative Poisson probabilities, the probability of obtaining five or fewer primary foci per plot was

TABLE 2. Estimated beta-binomial aggregation parameter at each disease assessment

\begin{tabular}{|c|c|c|c|c|}
\hline $\begin{array}{l}\text { Plot } \\
\text { assessment }\end{array}$ & $\hat{\theta}$ & $\begin{array}{c}\text { Standard } \\
\text { error }\end{array}$ & $\begin{array}{c}\text { Likelihood } \\
\text { ratio statistic }\end{array}$ & $P$ value $^{\mathrm{a}}$ \\
\hline$P_{1}-1$ & & & & \\
\hline$P_{1}-2$ & 0.0339 & 0.0227 & 28.8 & $<0.001$ \\
\hline$P_{1}-3$ & 0.0801 & 0.0278 & 131 & $<0.001$ \\
\hline$P_{1}-4$ & 0.2533 & 0.0582 & 707 & $<0.001$ \\
\hline$P_{1}-5$ & 0.3202 & 0.0608 & 1,011 & $<0.001$ \\
\hline$P_{1}-6$ & 0.3203 & 0.0602 & 1,017 & $<0.001$ \\
\hline$P_{2^{-1}}$ & 0.0214 & 0.0171 & 15.9 & $<0.001$ \\
\hline$P_{2}-2$ & 0.1877 & 0.0763 & 314 & $<0.001$ \\
\hline$P_{2^{-}} 3$ & 0.3991 & 0.1244 & 861 & $<0.001$ \\
\hline $\mathrm{P}_{2}-4$ & 0.5125 & 0.1515 & 1,113 & $<0.001$ \\
\hline$P_{2}-5$ & 0.6247 & 0.1694 & 1,440 & $<0.001$ \\
\hline $\mathrm{P}_{2}-6$ & 0.6199 & 0.1626 & 1,484 & $<0.001$ \\
\hline $\mathrm{P}_{3}-1$ & 0.0071 & 0.0098 & 2.7 & 0.05 \\
\hline $\mathrm{P}_{3}-2$ & 0.1252 & 0.0721 & 135 & $<0.001$ \\
\hline$P_{3-3}$ & 0.2023 & 0.0861 & 299 & $<0.001$ \\
\hline $\mathrm{P}_{3}-4$ & 0.6080 & 0.1637 & 1,342 & $<0.001$ \\
\hline$P_{3}-5$ & 0.5709 & 0.1197 & 1,722 & $<0.001$ \\
\hline$P_{3}-6$ & 0.4649 & 0.0822 & 1,745 & $<0.001$ \\
\hline$P_{4-7}$ & 0.4641 & 0.0818 & 1,737 & $<0.001$ \\
\hline$P_{4-1}$ & 0.0161 & 0.0181 & 6.8 & 0.004 \\
\hline$P_{4}-2$ & 0.1467 & 0.1252 & 85 & $<0.001$ \\
\hline $\mathrm{P}_{4^{-}} 3$ & 0.3352 & 0.2057 & 302 & $<0.001$ \\
\hline $\mathrm{P}_{4-4}$ & 0.4321 & 0.1979 & 537 & $<0.001$ \\
\hline $\mathrm{P}_{4}-5$ & 0.4816 & 0.2032 & 639 & $<0.001$ \\
\hline$P_{4}-6$ & 0.4810 & 0.1970 & 669 & $<0.001$ \\
\hline$P_{5}-1$ & 0.0381 & 0.0754 & 6.6 & 0.005 \\
\hline$P_{5}-2$ & 0.0858 & 0.1167 & 24.5 & $<0.001$ \\
\hline $\mathrm{P}_{5^{-}} 3$ & 0.2012 & 0.1909 & 101 & $<0.001$ \\
\hline $\mathrm{P}_{5}-4$ & 0.2920 & 0.2053 & 213 & $<0.001$ \\
\hline$P_{5}-5$ & 0.3364 & 0.2342 & 243 & $<0.001$ \\
\hline
\end{tabular}

a $P$ value is calculated by testing the square root of the likelihood ratio statistic as a standardized normal deviate.

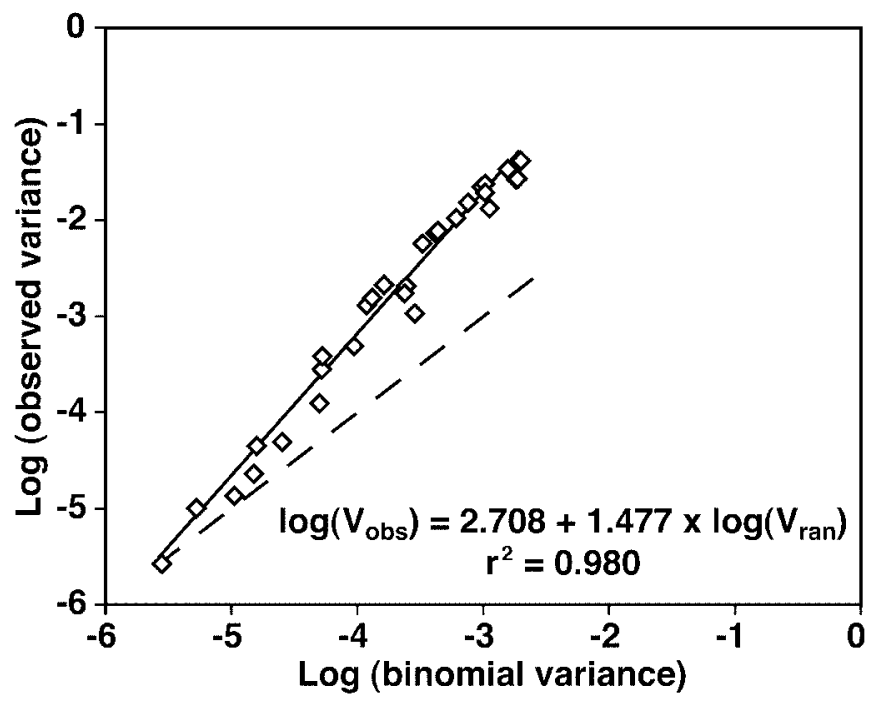

Fig. 3. Relationship between the logarithm of the observed variance $\left[\log \left(V_{\text {obs }}\right)\right]$ and the $\operatorname{logarithm}$ of the binomial variance, $\log [\hat{p}(1-\hat{p}) / \bar{n}]$, of disease incidence in five experimental plots sown with Xanthomonas axonopodis pv. allii-contaminated seed during three successive onion cropping seasons (at a different location each year) in Réunion Island (quadrat size of $1 \mathrm{~m}^{2}$, each containing up to 80 plants). The broken line represents the binomial line (i.e., observed variance $=$ theoretical binomial variance). 
found to be equal to 0.95 . Fifteen days after the first observation of disease, one and two new foci appeared in plots $\mathrm{P}_{2}$ and $\mathrm{P}_{3}$, respectively. These foci were separated from the nearest primary foci by approximately 7,4 , and $4 \mathrm{~m}$, respectively, and all were located northwest of primary foci. No more remote secondary foci appeared later on. In the outer rings sown with presumed "healthy" onion seed, symptoms were first observed on 30 October 2000 and on 7 November 2001 (Fig. 1). Distance from outer foci to the closest foci in experimental plots ranged from 14 to $25 \mathrm{~m}$.

In 1999, from sowing to lodging of shoots, 33 rainy days were observed, representing $235 \mathrm{~mm}$ of cumulative rainfall. In 2000 and 2001, $18(76 \mathrm{~mm})$ and $16(148 \mathrm{~mm})$ rainy days were observed (Fig. 1). August and July are annually the coolest months in Réunion Island, with average temperatures of $<20^{\circ} \mathrm{C}$. Over the 3 years, the average temperatures increased, starting at the end of August. Moreover, the climatic conditions recorded annually from September to December were close to means recorded over 30 years (i.e., hot and dry weather prevailed, with some occurrences of polar depressions characterized by stronger winds, heavy rainfall, and a fall in temperature). Such polar depressions had wind-driven rains with wind speeds of $\leq 15 \mathrm{~m} \mathrm{~s}^{-1}$.

Temporal analysis. All the models fitted, except the exponential model, provided a satisfactory description of the disease progress curve for each plot. Overall, the complementary log-log model was the most appropriate. The absolute rate $\left(r^{*} K\right)$ values were high for plot $\mathrm{P}_{1}(0.0156)$ and $\mathrm{P}_{3}(0.0124)$, intermediate for $\mathrm{P}_{2}$ (0.0046), and low for $\mathrm{P}_{4}(0.0023)$ and $\mathrm{P}_{5}(0.0008)$ (Table 1).
The amount of time after sowing necessary to get $50 \%$ of maximal disease incidence $(0.5 K)$ ranged from 92 to 119 days (Table 1). The maximum mean disease incidence ranged from 0.0059 on plot $\mathrm{P}_{5}$ to 0.1583 on plot $\mathrm{P}_{3}$ (Fig. 2). The highest disease incidence levels were observed in 1999 and 2000. In 2001, low levels of disease incidence were detected on $\mathrm{P}_{4}$ and $\mathrm{P}_{5}$.

Spatial analysis. Distribution analyses. Maximum likelihood estimates of $\theta$ were calculated for 29 out of 30 disease assessments (Table 2). The only exception was the first disease assessment for plot $\mathrm{P}_{1}$, when only 1 plant of 6,050 in the plot was found to be diseased. In all cases where a maximum likelihood estimate of $\theta$ was calculated successfully, the associated LRS indicated that the beta-binomial distribution provided a better fit to the data than the binomial distribution (Table 2).

Binary power law analyses. The binary power law provided a satisfactory description of the relationship between $\log \left(V_{\text {obs }}\right)$ and $\log \left(V_{\text {ran }}\right)$ with an $R^{2}$ value of 0.98 (Fig. 3). The intercept $\log \left(A_{x}\right)$ was 2.71 (standard error $=0.15$ ) and slope $b$ was 1.48 (standard error $=0.04)$.

Spatial autocorrelation. Spatial autocorrelation analysis indicated aggregated disease patterns (presence of core clusters of SL+ spatial lags) (Table 3). For all plots, the aggregation of disease occurred first within rows and later across rows. However, at the end of the experiment, the number of SL+ distance positions within and across rows was similar in three of four experimental plots (Table 3). The size of the core cluster increased for plot $\mathrm{P}_{2}$ at the end of the experiment because foci had coalesced. Few reflected clusters of small size (one SL+ in plots $\mathrm{P}_{3}$ and $\mathrm{P}_{4}$ and one

TABLE 3. Spatial autocorrelation analysis and associated statistics of four plots sown with Xanthomonas axonopodis pv. allii-contaminated seed during three successive onion cropping seasons in Réunion Island (quadrat size of $1 \mathrm{~m}^{2}$ containing $\approx 80$ plants)

\begin{tabular}{|c|c|c|c|c|c|c|c|c|c|c|c|}
\hline \multirow{2}{*}{$\begin{array}{l}\text { Plot, days } \\
\text { after sowing }\end{array}$} & \multirow[b]{2}{*}{ Incidence $^{\mathrm{a}}$} & \multicolumn{2}{|c|}{ Significant lags ${ }^{\mathrm{b}}$} & \multirow[b]{2}{*}{ Aggregation $^{c}$} & \multirow[b]{2}{*}{ Core $^{\mathrm{d}}$} & \multirow[b]{2}{*}{ Noncore $^{\mathrm{e}}$} & \multirow[b]{2}{*}{ Clusters $^{f}$} & \multicolumn{3}{|c|}{ Effects ${ }^{\mathrm{g}}$} & \multirow[b]{2}{*}{ Nonrandom $^{\mathrm{h}}$} \\
\hline & & SL+ & SL- & & & & & Within & Across & Edge & \\
\hline \multicolumn{12}{|l|}{$\mathrm{P}_{1}$} \\
\hline 81 & 0.003 & 1 & 0 & 1.000 & 1 & $\ldots$ & 1 & 0 & 1 & 0.00 & 0.012 \\
\hline 96 & 0.017 & 2 & 0 & 1.000 & 2 & $\ldots$ & 1 & 1 & 1 & 0.00 & 0.025 \\
\hline 109 & 0.073 & 4 & 2 & 0.750 & 3 & $1-2$ & 3 & 1 & 1 & 0.00 & 0.049 \\
\hline 123 & 0.125 & 7 & 3 & 0.571 & 4 & $2-3$ & 3 & 2 & 1 & 0.00 & 0.086 \\
\hline 137 & 0.128 & 7 & 3 & 0.571 & 4 & $2-3$ & 2 & 2 & 1 & 0.00 & 0.086 \\
\hline \multicolumn{12}{|l|}{$\mathrm{P}_{2}$} \\
\hline 63 & 0.002 & 3 & 0 & 0.000 & 0 & $1-2$ & 2 & 0 & 0 & 0.00 & 0.037 \\
\hline 77 & 0.016 & 4 & 0 & 0.250 & 1 & 1 & 4 & 1 & 0 & 0.00 & 0.049 \\
\hline 91 & 0.043 & 9 & 0 & 0.333 & 3 & $1-2-3$ & 4 & 2 & 1 & 0.11 & 0.111 \\
\hline 105 & 0.054 & 10 & 0 & 0.400 & 4 & $1-1-1-3$ & 5 & 3 & 1 & 0.10 & 0.123 \\
\hline 119 & 0.070 & 11 & 0 & 0.600 & 6 & $1-1-3$ & 4 & 3 & 1 & 0.09 & 0.136 \\
\hline 133 & 0.075 & 11 & 0 & 0.909 & 10 & 1 & 2 & 3 & 3 & 0.09 & 0.136 \\
\hline \multicolumn{12}{|l|}{$\mathrm{P}_{3}$} \\
\hline 63 & 0.001 & 1 & 0 & 0.000 & 0 & 1 & 1 & 0 & 0 & 1.00 & 0.012 \\
\hline 77 & 0.006 & 3 & 0 & 0.333 & 1 & 1 & 3 & 1 & 0 & 0.33 & 0.037 \\
\hline 91 & 0.016 & 2 & 0 & 0.500 & 1 & 1 & 2 & 1 & 0 & 0.50 & 0.025 \\
\hline 105 & 0.073 & 3 & 0 & 0.667 & 2 & 1 & 2 & 1 & 1 & 0.33 & 0.037 \\
\hline 119 & 0.119 & 4 & 1 & 0.500 & 2 & 1 & 3 & 1 & 1 & 0.25 & 0.049 \\
\hline 133 & 0.156 & 4 & 2 & 0.500 & 2 & 1 & 3 & 1 & 1 & 0.25 & 0.049 \\
\hline 147 & 0.159 & 4 & 2 & 0.500 & 2 & 1 & 3 & 1 & 1 & 0.25 & 0.049 \\
\hline \multicolumn{12}{|l|}{$\mathrm{P}_{4}$} \\
\hline 88 & 0.003 & 2 & 0 & 0.000 & 0 & 1 & 2 & 0 & 0 & 0.00 & 0.025 \\
\hline 102 & 0.010 & 2 & 0 & 0.000 & 0 & 1 & 2 & 0 & 0 & 0.00 & 0.025 \\
\hline 116 & 0.021 & 4 & 0 & 0.250 & 1 & 1 & 4 & 1 & 0 & 0.00 & 0.049 \\
\hline 130 & 0.026 & 4 & 0 & 0.250 & 1 & 1 & 4 & 1 & 0 & 0.00 & 0.049 \\
\hline 144 & 0.028 & 3 & 0 & 0.667 & 2 & 1 & 2 & 1 & 1 & 0.00 & 0.037 \\
\hline
\end{tabular}

${ }^{\mathrm{a}}$ Disease incidence $=$ number of diseased plants divided by total number of plants per plot.

${ }^{\mathrm{b}}$ Significant lags $=$ the number of $x, y$ lag distance positions within the proximity pattern with autocorrelations significantly greater (SL+) or significantly less (SL-) than expected.

${ }^{c}$ Strength of aggregation = estimate of the density of the core cluster, calculated as the proportion of SL+ within the area circumscribed by the outer row and the outer column of the core cluster within the proximity pattern.

${ }^{\mathrm{d}}$ Core cluster size $=$ number of SL+ contiguous with the origin of the proximity matrix that form a discrete group.

e Size of noncore clusters $=$ number of SL+ that form a discrete group within the proximity matrix but which are discontinuous with the core cluster.

${ }^{\mathrm{f}}$ Total number of clusters $=$ number of discrete groups of SL+ within the proximity pattern that are discontinuous with the core cluster.

${ }^{\mathrm{g}}$ Row effects $=$ the number of SL+ distance positions within the first row (within) or within the first column (across) of the autocorrelation proximity pattern which are contiguous with the origin. Edge effects $=$ the proportion of the lag positions within the last row and within the last column in the proximity pattern that are SL+.

${ }^{\mathrm{h}}$ Strength of nonrandomness $=$ the proportion of $(\mathrm{SL}+)+(\mathrm{SL}-)$ positions within the proximity matrix. 
to three contiguous $\mathrm{SL}+$ in plots $\mathrm{P}_{1}$ and $\mathrm{P}_{2}$ ) were recorded in all plots, indicating that relationships among individual foci did not exist or were weak. Secondary foci either developed independently of preexisting ones (plots $\mathrm{P}_{3}$ and $\mathrm{P}_{4}$ ) or sometimes coalesced (plot $\mathrm{P}_{2}$ ) (Table 3). Edge effects were most often absent or weak (plots $\mathrm{P}_{2}$ and $\mathrm{P}_{3}$ ). The strength of aggregation generally was moderate to high due to the presence of few primary foci and limited spatial progress of disease, without coalescence of primary foci. The strength of nonrandomness always was low, indicating that areas with aggregated diseased plants composed only a small proportion of the plot (Table 3).

Geostatistical analysis. Spherical and exponential models were good descriptors of the semivariograms. A fit of data with spherical model confirmed that disease patterns were aggregated. The nugget values $\left(C_{0}\right)$ ranged from 0.399 to 0.445 (Table 4 ). Spatial dependency ranged from 1.055 to $2.218 \mathrm{~m}$. Anisotropy was not detected, indicating that spread of $X$. axonopodis pv. allii did not have one predominant direction. Kriging of data indicated that primary foci were dispersed in plot $\mathrm{P}_{3}$ and $\mathrm{P}_{4}$ (Fig. 4). They

TABLE 4. Semivariance analysis and associated statistics for three plots sown with Xanthomonas axonopodis pv. allii-contaminated seed

\begin{tabular}{lccccc}
\hline Plot & Model & Nugget $^{\mathrm{a}}$ & Sill $^{\mathrm{b}}$ & RSD $^{\mathrm{c}}$ & $R^{2}$ \\
\hline $\mathrm{P}_{2}$ & Spherical & 0.403 & 0.795 & 1.055 & 0.951 \\
$\mathrm{P}_{3}$ & Spherical & 0.399 & 1.199 & 2.218 & 0.995 \\
$\mathrm{P}_{4}$ & Spherical & 0.445 & 1.218 & 1.660 & 0.993 \\
\hline
\end{tabular}

a Nugget (also written $C_{0}$ ) is the $y$ intercept and indicates the level of aggregation (the lower the nugget, the higher the aggregation).

b Sill (also written $C_{0}+C$ ) is the $y$ axis point corresponding to the model asymptote.

c RSD (also written $A_{0}$ ) = range of spatial dependency (i.e., the distance over which spatial dependence is apparent). mostly were clumped in the north-oriented quarter of plot $\mathrm{P}_{2}$ (Fig. 4). Later in the epidemics, primary foci in plot $P_{2}$ coalesced, as shown by low values of sill and range observed on semivariograms (Table 4).

\section{DISCUSSION}

The increase of international trade and human travel in recent years has dramatically accelerated introductions of pathogens in agricultural systems, some of which are transported in association with seed (30). This work was undertaken to determine, from epidemiological studies, the biological significance of seedborne $X$. axonopodis pv. allii (41) as initial inoculum for the development of bacterial blight of onion. The spatial and temporal patterns of BBO after sowing of naturally $X$. axonopodis pv. alliicontaminated seed were characterized over 3 years.

BBO appeared annually after a period of latent infection that could correspond to an epiphytic or endophytic colonization by $X$. axonopodis pv. allii of the onion phyllosphere without symptom expression (42). Symptoms of BBO were not observed during austral winter months, July and August, characterized by mean temperatures of 19 to $20^{\circ} \mathrm{C}$ (Fig. 1). The effect of temperature on the length of the latent period has been estimated in other pathosystems associated with xanthomonads $(22,37,45)$. The latent period was determined to be 17 to 21 days after inoculation of citrus plants with $X$. axonopodis pv. citri in a greenhouse where the mean temperature was $\approx 20^{\circ} \mathrm{C}(22)$. Epidemiological field experiments were conducted for $\approx 30$ days in Réunion Island with the same bacterium, when mean temperatures of $\approx 20^{\circ} \mathrm{C}$ followed a meteorological event allowing bacterial dissemination (37). Moreover, it has been reported that infection by $X$. axonopodis $\mathrm{pv}$. citri may not occur below $20^{\circ} \mathrm{C}$ (4). Similarly, symptoms of black
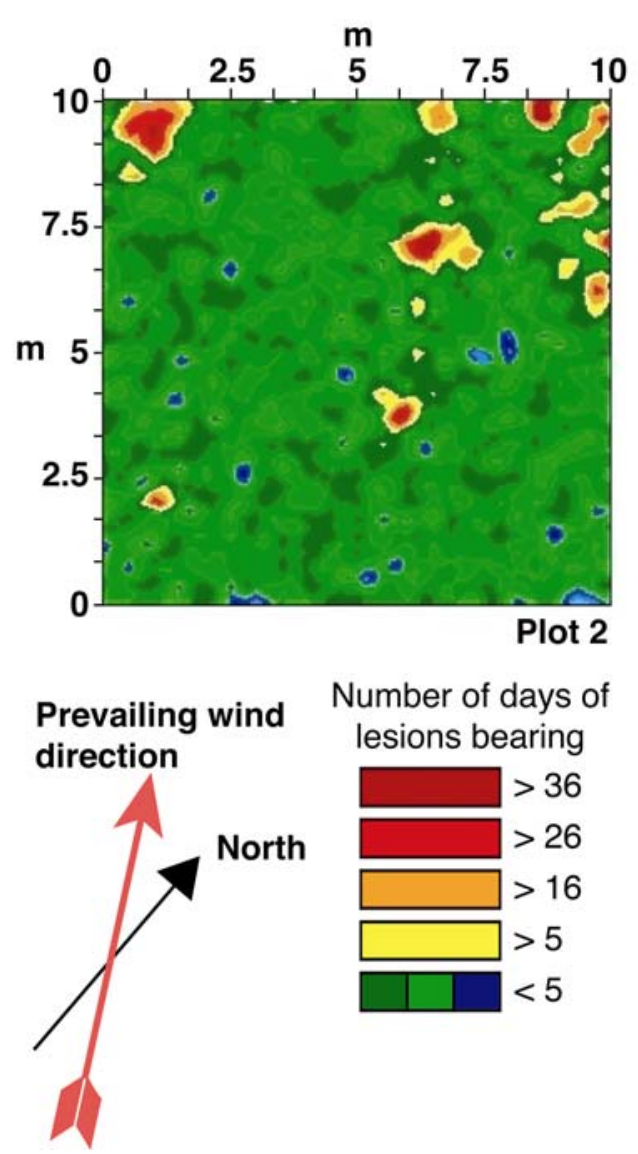

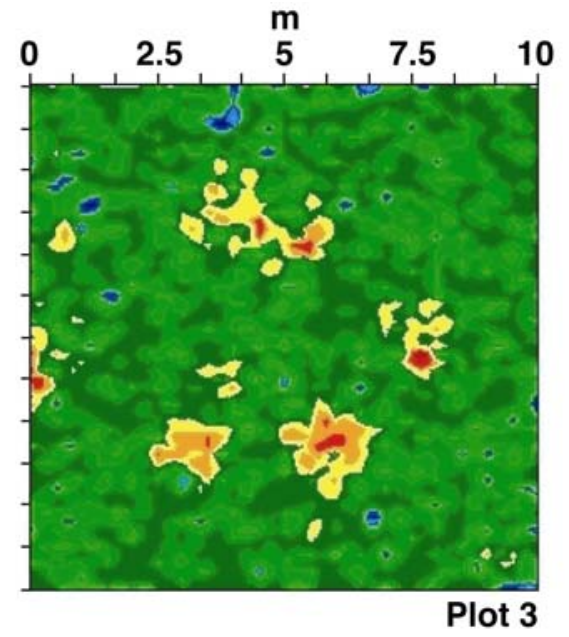

Number of days of lesions bearing

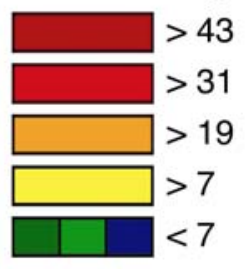

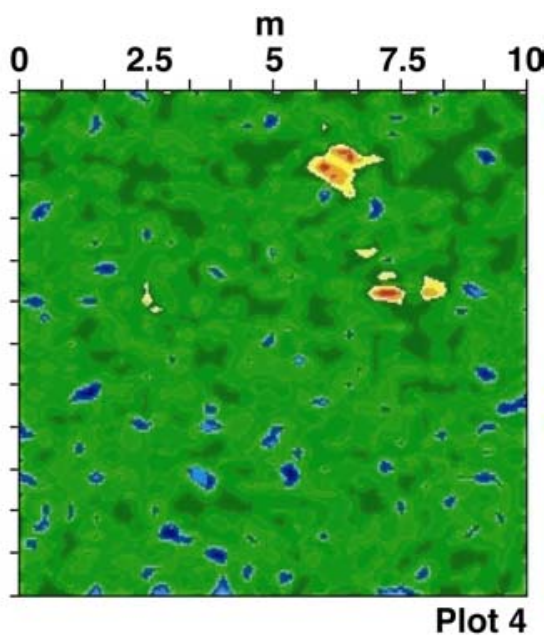

Number of days of lesions bearing

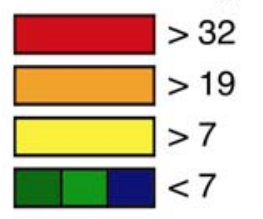

Fig. 4. Kriging estimate maps based on the temporal value calculated as the number of days of lesions bearing relative to the final assessment date of the experiment in three plots sown in 2000 and 2001 with Xanthomonas axonopodis pv. allii-contaminated seed in Réunion Island. 
rot, caused by $X$. campestris pv. campestris, are not expressed at temperatures below 18 to $20^{\circ} \mathrm{C}(45)$. In the present work, BBO appeared each year in plots sown with onion seed contaminated with $X$. axonopodis pv. allii, but dates of initial disease development were different and ranged from 63 to 88 days after sowing. Over the 3 years, development of disease symptoms was related to a succession of two climatic events: occurrences of windy and rainy days followed by increases in temperatures (Fig. 1). Those favorable weather conditions probably affected the multiplication of $X$. axonopodis pv. allii in plant tissues, resulting in the appearance of symptoms (42). In 2001, disease appearance was late and probably related to the occurrence of an extended (42 consecutive days) period of cool and dry weather prior to the occurrence of climatic conditions conducive to disease development (Fig. 1). BBO appeared annually whatever the level of soil moisture (data not shown), induced by the different annual winter climatic conditions. This result is consistent with those obtained by Roberts et al. (38), who reported no effect of compost moisture on transmission rate of $X$. campestris pv. campestris.

A nonlinear complementary log-log model adequately represented temporal progress curves of BBO. The drying of onion leaves, effectively preventing development of new infections in the weeks preceding harvest, brought about a slowing of the rate of disease progress toward an asymptotic upper level of disease (Fig. 2). For each plot, the amount of time to reach $0.5 \mathrm{~K}$ ranged from 92 to 119 days after sowing. Those durations corresponded in each case to onion bulbing, a critical growth stage for $\mathrm{BBO}$ development (i.e., when contact along and across rows between diseased and healthy leaves in the fully developed canopy facilitates disease spread) (51).

Spatial analyses of quadrat data indicated aggregated patterns of disease incidence at that scale. Generally, the beta-binomial distribution provided a better fit to observed data than the binomial distribution (Table 2). Estimates of the beta-binomial aggregation parameter $\theta$ obtained for BBO were similar to estimates determined for diseases caused by splash-dispersed fungi $(28,53$, $60,61)$, and were higher than those determined for pathosystems for which insect vectors occur $(15,56)$. The binary power law also characterized quadrat-scale aggregation in disease incidence data (Fig. 3). The intercept $\log \left(A_{x}\right)$ and slope $b$ both exceeded 1 (Fig. 3 ), indicating that the degree of aggregation varied with the disease incidence (26).

Primary foci enlarged over time. Spatial dependency, derived from semivariance analysis, ranged from 1.1 to $2.2 \mathrm{~m}$ (Table 4). Based on the evolution and shape of core clusters (Table 3), spatial autocorrelation analysis further confirmed that the spatial development of BBO was limited mostly to a localized dispersal. The shape of core clusters, as determined by spatial autocorrelation analysis (Table 3), and the absence of anisotropy, as determined by directional semivariograms (data not shown), indicated a lack of directionality of $X$. axonopodis pv. allii dissemination. These results suggest the importance of overhead irrigation regime over wind-driven rains (which most often had a northwest direction) in the development and enlargement of foci. These results are consistent with previously published data on cabbage black rot disease $(20,21)$.

Only a limited number of secondary foci established after the occurrence of wind-driven rains. Distances between primary and secondary foci ranged from $<1 \mathrm{~m}$ to a few meters (Fig. 4). The limited number and small size of reflected clusters, as revealed by spatial autocorrelation analysis (Table 3), indicated an absence of strong relationships among individual foci. The fact that edge effects were either absent or small (Table 3) was interpreted as an indicator that inoculum associated with epidemics predominantly had a within-plot origin.

The seed lot used for establishing experimental plots contained $0.04 \%$ X. axonopodis pv. allii-contaminated seeds. The number of primary foci that developed in the experimental plots ranged from one to five. These numbers were in the range of the expected number of foci with a seed contamination rate of $0.04 \%$ and emergence of 6,000 to 7,000 seedlings, given that primary foci are composed of a single infected plant at the beginning of the epidemics (which was experimentally verified) and each plant emerging from a contaminated seed becomes infected.

The establishment of outer rings, composed of onion plants originating from a seed lot with a $X$. axonopodis pv. allii contamination rate of $<1$ out of $10^{5}$ seed and separated from experimental plots by maize windbreaks, was intended for monitoring potential long-distance dispersal of $X$. axonopodis pv. allii. As far as the present report is concerned, the fact that BBO appeared in outer rings 47 and 42 days after the appearance of disease foci in experimental plots sown with $X$. axonopodis pv. alliicontaminated seed in 2000 and 2001, respectively, (Fig. 1) effectively rules out long-distance dispersal of inoculum into the experimental plots via the outer plots as the source of initial inoculum.

Thus, the recorded number of primary foci was consistent with the absence, at least early in the epidemics, of disease development from initial inoculum associated with dispersal of $X$. axonopodis pv. allii into the experimental plots over long distances. Based on (i) the narrow host range of $X$. axonopodis pv. allii (restricted to Allium spp.) (40), (ii) the lack of host species among weeds on the experimental site, (iii) the absence of host cropping on the experimental site for at least a decade, and (iv) the poor ability of xanthomonads to survive for long periods in soil (55), it is likely that the initial inoculum associated with the initial stages of epidemics had a seedborne origin. This assumption is fully consistent with previously published data, which showed that epidemics of black rot of crucifers caused by $X$. campestris pv. campestris developed with a high disease incidence from seed lots containing $0.03 \%$ contaminated seed (47). Available molecular typing techniques based on restriction fragment length polymorphism and amplified fragment length polymorphism did not discriminate among genetically related populations (39) that usually occur at a microgeographic scale, and therefore, cannot be used to compare $X$. axonopodis pv. allii populations detected from the seed lot and those associated with infected onion plants during the epidemics.

Although pesticide treatments and disease assessments were performed only when leaves were fully dry, occasional human movements in the experimental plots could not be precluded. Moreover, wind-driven rains with gusts up to $15 \mathrm{~m} \mathrm{~s}^{-1}$ were recorded each year during the later stages of the described epidemics. Thus, part of the inoculum associated with the later stages of the epidemics may have resulted from longer-distance dispersal. However, no readily available initial inoculum source other than seedborne inoculum was identified; therefore, also taking into consideration the spatial characteristics of the epidemics, it is likely that initial inoculum associated with the early stages of the described epidemics has a seedborne origin. These results emphasize the need to develop routine seed health quality assessments for BBO. The epidemics described here were produced under relatively dry conditions. More favorable climatic conditions should induce increased levels of disease incidence, as reported in other countries $(34,51)$.

\section{ACKNOWLEDGMENTS}

This work was funded by grants from Odéadom, European Union, and Conseil Général de la Réunion. We thank P. Rott (CIRAD, Montpellier, France) and Y. Sache (INRA, Grignon, France), for helpful discussions; J. L. Chopard (CIRAD, Saint Pierre, Réunion, France) and H. Quetelard (METEO-FRANCE, Saint Pierre, Réunion, France) for providing us with meteorological data from Réunion Island; and D. Gourc, D. Monnier, (Armeflhor, Saint Pierre, Réunion, France), A. Couteau, C. Hoareau, and W. Grondin (CIRAD, Saint Pierre, Réunion Island, France) for technical assistance. 


\section{LITERATURE CITED}

1. Alvarez, A. M., Buddenhagen, I. W., Buddenhagen, E. S., and Domen, H. Y. 1978. Bacterial blight of onion, a new disease caused by Xanthomonas sp. Phytopathology 68:1132-1136.

2. Bashan, Y., Okon, Y., and Henis, Y. 1982. Long-term survival of Pseudomonas syringae pv. tomato and Xanthomonas campestris pv. vesicatoria in tomato and pepper seeds. Phytopathology 72:1143-1144.

3. Campbell, C. L., and Madden, L. V. 1990. Introduction to Plant Disease Epidemiology. John Wiley \& Sons, New York.

4. Civerolo, E. L. 1984. Bacterial canker disease of citrus. J. Rio Grande Val. Hortic. Soc. 37:127-145.

5. Cochran, W. G. 1977. Sampling Techniques. 3rd ed. John Wiley \& Sons, New York.

6. Davidian, M., and Giltinan, D. M. 1995. Nonlinear regression models for individual data. Pages 17-62 in: Nonlinear Models for Repeated Measurement Data. Vol. 62, Monographs on Statistics and Applied Probability. CRC Press, Boca Raton, FL.

7. Gottwald, T. R. 1995. Spatio-temporal analysis and isopath dynamics of citrus scab in nursery plots. Phytopathology 85:1082-1092.

8. Gottwald, T. R., Avinent, L., Llacer, G., Hermoso, D. M., A., and Cambra, M. 1995. Analysis of the spatial spread of sharka (plum pox virus) in apricot and peach orchards in Eastern Spain. Plant Dis. 79:266-278.

9. Gottwald, T. R., Garnsey, S. M., and Borbon, J. 1998. Increase and patterns of spread of citrus tristeza virus infections in Costa Rica and the Dominican Republic in the presence of the brown citrus aphid, Toxoptera citricida. Phytopathology 88:621-636.

10. Gottwald, T. R., Richie, S. M., and Campbell, C. L. 1992. LCOR2Spatial correlation analysis software for the personal computer. Plant Dis. 76:213-215.

11. Gottwald, T. R., Sun, X., Riley, T., Graham, J. H., Ferrandino, F., and Taylor, E. L. 2002. Geo-referenced spatiotemporal analysis of the urban citrus canker epidemic in Florida. Phytopathology 92:361-377.

12. Huet, S., Bouvier, A., Gruet, M. A., and Jolivet, E. 1996. Accuracy of estimators, confidence intervals and tests. Pages 29-60 in: Statistical Tools for Nonlinear Regression. Springer-Verlag, New York.

13. Hughes, G., and Gottwald, T. R. 1998. Survey methods for assessment of citrus tristeza virus incidence. Phytopathology 88:715-723.

14. Hughes, G., and Madden, L. V. 1992. Aggregation and incidence of disease. Plant Pathol. 41:657-660.

15. Hughes, G., and Madden, L. V. 1993. Using the beta-binomial distribution to describe aggregated patterns of disease incidence. Phytopathology 83:759-763.

16. Hughes, G., Madden, L. V., and Munkvold, G. P. 1996. Cluster sampling for disease incidence data. Phytopathology 86:132-137.

17. Isakeit, T., Miller, M. E., Barnes, L. W., Dickstein, E. R., and Jones, J. B. 2000. First report of leaf blight of onion caused by Xanthomonas campestris in the continental United States. Plant Dis. 84:201.

18. Kadota, I., Uehara, K., Shinohara, H., and Nishiyama, K. 2000. Bacterial blight of welsh onion: A new disease caused by Xanthomonas campestris pv. allii pv. nov. J. Gen. Plant Pathol. 66:310-315.

19. Kocks, C. G., Ruissen, M. A., Zadoks, J. C., and Duijkers, M. G. 1998. Survival and extinction of Xanthomonas campestris pv. campestris in soil. Eur. J. Plant Pathol. 104:911-923.

20. Kocks, C. G., Zadoks, J. C., and Ruissen, M. A. 1998. Response of black rot in cabbage to spatial distribution of inoculum. Eur. J. Plant Pathol. 104:713-723.

21. Kocks, C. G., Zadoks, J. C., and Ruissen, M. A. 1999. Spatio-temporal development of black rot (X. campestris pv. campestris) in cabbage in relation to initial inoculum levels in field plots in The Netherlands. Plant Pathol. 48:176-188.

22. Koizumi, M. 1976. Incubation period of citrus canker in relation to temperature. Bull. Fruit Tree Res. Stn. Jpn. B 3:33-46.

23. Kuan, T. L., Minsavage, G. V., and Gabrielson, R. L. 1985. Detection of Xanthomonas campestris pv. carotae in carrot seed. Plant Dis. 69:758760.

24. Lecoustre, R., Fargette, D., Fauquet, C., and De Reffye, P. 1989. Analysis and mapping of the spatial spread of African cassava mosaic virus using geostatistics and the Kriging technique. Phytopathology 79:913-920.

25. Madden, L. V., and Hughes, G. 1994. BBD-computer software for fitting the beta-binomial distribution to disease incidence data. Plant Dis. 78:536-540.

26. Madden, L. V., and Hughes, G. 1995. Plant disease incidence: Distribution, heterogeneity, and temporal analysis. Annu. Rev. Phytopathol. 33:529-564.

27. Madden, L. V., and Hughes, G. 1999. Sampling for plant disease incidence. Phytopathology 89:1088-1103.

28. Madden, L. V., Hughes, G., and Ellis, M. A. 1995. Spatial heterogeneity of the incidence of grape downy mildew. Phytopathology 85: 269-275.
29. Madden, L. V., and Nutter, F. W. 1995. Modeling crop losses at the field scale. Can. J. Plant Pathol. 17:124-137.

30. Maddox, D. A. 1998. Implications of new technologies for seed health testing and the worldwide movement of seed. Seed Sci. Res. 8:277-284.

31. Masmoudi, K., Duby, C., Suhas, M., Guo, J. Q., Taylor, J. D., and Maury, Y. 1994. Quality control of pea seed for pea seed-borne mosaic virus. Seed Sci. Technol. 22:407-414.

32. Modjeska, J. S., and Rawlings, J. O. 1983. Spatial correlation analysis of uniformity data. Biometrics 39:373-384.

33. Neto, J. R., Malavolta, V. A., Jr., Cardelli, M. A., and Sinigaglia, C. 1987. Ocorrencia de uma nova doença bacteriana em cebola, no estado de Sao Paulo. Summa Phytopathol. 13:10.

34. Nunez, J. J., Gilbertson, R. L., Meng, X., and Davis, R. M. 2002. First report of Xanthomonas leaf blight of onion in California. Plant Dis. 86:330.

35. O'Garro, L. W., and Paulraj, L. P. 1997. Onion leaf blight caused by Xanthomonas campestris: Alternative hosts and resistant onion genotypes. Plant Dis. 81:978-982.

36. Paulraj, L., and O'Garro, L. W. 1993. Leaf blight of onions caused by Xanthomonas campestris. Plant Dis. 77:198-201.

37. Pruvost, O., Gottwald, T. R., and Brocherieux, C. 1999. The effect of irrigation practices on the spatio-temporal increase of Asiatic citrus canker in simulated nursery plots in Réunion Island. Eur. J. Plant Pathol. 105:23-37.

38. Roberts, S. J., Hiltunen, L. H., Hunter, P. J., and Brough, J. 1999. Transmission from seed to seedling and secondary spread of Xanthomonas campestris pv. campestris in Brassica transplants: Effects of dose and watering regime. Eur. J. Plant Pathol. 105:879-889.

39. Roumagnac, P. 2003. Taxonomie et diversité du Xanthomonas responsable du dépérissement bact'rien de l'oignon. Etudes épidémiologiques du rôle des semences dans la transmission de la bactérie. Ph.D. thesis, INA P-G, Paris.

40. Roumagnac, P., Gagnevin, L., Gardan, L., Sutra, L., Manceau, C., Dickstein, E. R., Jones, J. B., Rott, P., and Pruvost, O. 2004. Polyphasic characterization of xanthomonads isolated from onion, garlic and Welsh onion (Allium spp.) and their relatedness to different Xanthomonas species. Int. J. Syst. Evol. Microbiol. 54:15-24.

41. Roumagnac, P., Gagnevin, L., and Pruvost, O. 2000. Detection of Xanthomonas sp., the causal agent of onion bacterial blight, in onion seeds using a newly developed semi-selective isolation medium. Eur. J. Plant Pathol. 106:867-877.

42. Rudolph, K. 1993. Infection of the plant by Xanthomonas. Pages 193-264 in: Xanthomonas. J. G. Swings and E. L. Civerolo, eds. Chapman \& Hall, London.

43. Sanders, F. H., Langston, D. B., Jr., Brock, J. H., Gitaitis, R. D., Curry, D. E., and Torrance, R. L. 2003. First report of a leaf blight of onion caused by Xanthomonas spp. in Georgia. Plant Dis. 87:749.

44. Savary, S., Castilla, N. P., and Willocquet, L. 2001. Analysis of the spatiotemporal structure of rice sheath blight epidemics in a farmer's field. Plant Pathol. 50:53-68.

45. Schaad, N. W. 1982. Detection of seedborne bacterial plant pathogens. Plant Dis. 66:885-890.

46. Schaad, N. W., and Kenkrick, R. 1975. A qualitative method of detecting Xanthomonas campestris in crucifer seed. Phytopathology 65:1034-1036.

47. Schaad, N. W., Sitterly, W. R., and Humaydan, H. 1980. Relationship of incidence of seedborne Xanthomonas campestris to black rot of crucifers. Plant Dis. 64:91-92.

48. Schotzko, D. J., and O'Keeffe, L. E. 1989. Geostatistical description of the spatial distribution of Lygus hesperus (Heteroptera: Miridae) in lentils. J. Econ. Entomol. 82:1277-1288.

49. Schotzko, D. J., and O'Keeffe, L. E. 1990. Effect of sample placement on the geostatistical analysis of the spatial distribution of Lygus hesperus (Heteroptera: Miridae) in lentils. J. Econ. Entomol. 83:1888-1900.

50. Schwartz, H. F., and Otto, K. 2000. First report of leaf blight of onion caused by Xanthomonas campestris in Colorado. Plant Dis. 84:922.

51. Schwartz, H. F., Otto, K. L., and Gent, D. H. 2003. Relation of temperature and rainfall to development of Xanthomonas and Pantoea leaf blights of onion in Colorado. Plant Dis. 87:11-14.

52. Serfontein, J. J. 2001. Xanthomonas blight of onion in South Africa. Plant Dis. 85:442.

53. Shah, D. A., Bergstrom, G. C., and Ueng, P. P. 2001. Foci of Stagonospora nodorum blotch in winter wheat before canopy development. Phytopathology 91:642-647.

54. Shigaki, T., Nelson, S. C., and Alvarez, A. M. 2000. Symptomless spread of blight-inducing strains of Xanthomonas campestris pv. campestris on cabbage seedlings in misted seedbeds. Eur. J. Plant Pathol. 106:339-346.

55. Stall, R. E., Gottwald, T. R., Koizumi, M., and Schaad, N. C. 1993. Ecology of plant pathogenic xanthomonads. Pages 265-299 in: Xanthomonas. J. G. Swings and E. L. Civerolo, eds. Chapman \& Hall, London.

56. Tanne, E., Marcus, R., Dubitzky, E., and Raccah, B. 1996. Analysis of progress and spatial pattern of corly bark in grapes. Plant Dis. 80:34-38. 
57. Taylor, L. R. 1961. Aggregation, variance and the mean. Nature 189:732735.

58. Trujillo, G., and Hernandez, Y. 1999. Identificacion de bacterias fitopatogenas en semillas de plantas cultivadas. Paper read at XVI Congreso Venezolano de Fitopatologia, Barquisimeto, Venezuela.

59. Tubajika, K. M., Tillman, B. L., Russin, J. S., and Harrison, S. A. 1998. Relationship between flag leaf symptoms caused by Xanthomonas translucens pv. translucens and subsequent seed transmission in wheat. Plant Dis. 82:1341-1344.
60. Turechek, W. W., and Madden, L. V. 1999. Spatial pattern analysis of strawberry leaf blight in perennial production systems. Phytopathology 89:421-433.

61. Turechek, W. W., and Madden, L. V. 2000. Analysis of the association between the incidence of two spatially aggregated foliar diseases of strawberry. Phytopathology 90:157-170.

62. Weller, D. M., and Saettler, A. W. 1980. Evaluation of seedborne Xanthomonas phaseoli and Xanthomonas phaseoli var. fuscans as primary inocula in bean blights. Phytopathology 70:148-152. 